\title{
Classroom Management: Implications on High School Students' Character Formation in Africa
}

\author{
Everlyn Oluoch- Suleh (Ph.D.) $)^{1 *}$, Osuji Gregory Ekene (Rev. Br. - Ph.D. $)^{2}$ \\ ${ }^{1}$ Marist International University College, P.O. Box 24450 Karen, 00502 Nairobi, Kenya \\ ${ }^{2}$ Godfrey Okoye University Ugwuomu-Nike, P.M.B. 01014, Thinkers' Corner, Enugu, Nigeria
}

\begin{tabular}{ll}
\hline DOI: $10.36348 /$ jaep.2020.v04i03.008 & | Received: 17.03 .2020 | Accepted: $24.03 .2020 \mid$ Published: 27.03 .2020 \\
*Corresponding author: Dr. Everlyn Oluoch - Suleh &
\end{tabular}

Abstract

Classroom management occupies a vital position in the pedagogical approach of the teacher and the life of high school students in Africa. Teachers who use laissez faire administrative style and methodology in the classrooms run the risk of aiding vices in students. Currently, it has been a social concern that there is increase in moral decadence. In addition, that many high school students are prone to some deviant behaviour due to ineffective classroom management. Effective classroom management is the key to curbing incidences of indiscipline such as disobedience, disrespect, lying, bullying, examination malpractice, and truancy among high school students of Africa. Effective classroom management through goal-oriented and specific instructional objectives, instructional strategies, and instructional resources helps students acquire the virtues of honesty, hard work, collaboration and responsibility, which leads to proper character formation and academic excellence of the learner. This qualitative study is anchored on the Classroom Management Theory of Thomas Gordon. This theory explicitly opines that an effective classroom management enhances productivity in the students. The study is solely based on document analysis of secondary data, and classroom observation. The findings of the study confirm that positive classroom climate enables the student to feel cared for and be engaged in school activities that lead to positive pursuits in life. The study therefore recommends that teachers should establish a positive learning environment by showing their passion for the subject matter, and being active in moving among the students.

Keywords: Classroom management, pedagogy, character formation, academic performance, students, Africa.

Copyright @ 2020: This is an open-access article distributed under the terms of the Creative Commons Attribution license which permits unrestricted use, distribution, and reproduction in any medium for non-commercial use (NonCommercial, or CC-BY-NC) provided the original author and sources are credited.

\section{INTRODUCTION}

Education brings about a change in the individual, which promotes greater productivity and work efficiency. It remains a major component in the development of human resources. Improvement of human resources is not limited to the inculcation of skills and knowledge. It includes having values, positive attitudes and motives consistent with the goals and methods of development plan that will benefit the future generations [1]. As a result, students need to eschew deviant acts and embrace discipline that will help them live a more successful life for the good of the society. This is because any society whose educational system does not consider the needs of the learner and that of the society is bound to fail.

Character formation of students is a concern to stakeholders in education. This is because there has been a social outcry on the incidences of indiscipline in high schools. The teacher is the key factor in helping learners fight these incidences of deviant behaviours and embrace hard work and virtue; the hallmark for character formation. He or she can effectively do this by proper classroom management.

In addressing the Italian Teachers' Union on $5^{\text {th }}$ January 1954, Pope Pius XII [2] exclaimed that:

A society that is interested in intellectual and moral values, a society that does not want to slip and slide towards that materialism, secularism and consumerism to which it is being drawn by weight of the ever more mechanical life of technical civilization, holds on to quality and credible education. (p. 15)

The teacher is the key factor in this Pope's message because of his or her role in curriculum implementation in schools. Research has shown that some of the teachers in high schools in Africa have little classroom management techniques. They are sometimes wanting in societal and Christian values, and creativity in teaching methodology [3]. With this, it may be difficult to expect maximum results from them on the character formation of students. This creates 
opportunities for students to be involved in incidences of indiscipline [4].

Individualised learning is the centre of transfer of knowledge, values, skills, and attitudes in the education sector today. In order to ensure character formation of students, the school environment needs to be conducive to teaching and learning. The classroom in a special way is the centre of learning in most schools. Therefore, the teacher's role in managing the classroom is vital to students' character formation and academic excellence.

In order for education to lead its informative, formative and transformative roles in the learner, students need to be fully involved in classroom activities. They need to participate in the discourse of the discipline to think, speak, and be listened to as they participate in the discipline's particular mode of inquiry. This aids learners to develop competency and become critical thinkers in classroom that provides opportunities for intensive, structured interaction among them. The interaction between the teacher and the students is an essential part of teaching and learning process. This is because classroom interaction stimulates the learner's involvement in the classroom. It fuels the learner's motivation and helps him or her to see the relevance of the lesson [5].

Brophy [6] defines classroom management as "actions taken to create and maintain a learning environment conducive to successful instruction (arranging the physical environment, establishing rules and procedures, maintaining students' attention to lessons and engagement in activities)" (p. 17). Based on this definition therefore, teachers who play a fundamental role in the cognitive, affective, and psychomotor domains of learning of the high school student needs to give him or her the opportunity to develop his or her character properly through effective classroom management. Effective classroom management sets the stage for character formation. Without effective classroom management, classrooms are disorganized and chaotic, and very little academic learning and value formation can happen [7]. Effective classroom interaction and management is the key to integral formation of the learner. It facilitates group work and enables the learner to develop his or her personality in a very positive way. It gives the learner many opportunities to respect and value the opinions of others. It also helps the learner to learn and understand how to work with others. By so doing, it helps to develop and improve the skills of teamwork; hence, cohesiveness, which is the core to character formation and societal transformation.

Effective teaching and learning for students' character formation cannot take place in poorly managed classrooms [8]. Therefore, the teacher, a big stakeholder in the teaching and learning process needs to devise varied classroom management techniques to redirect the behaviour of learners to positive pursuits. This calls for behavioural agreement at the beginning of the term. This is because effective classroom management supports and facilitates effective teaching and learning for academic excellence and character formation of students.

Effective classroom management is generally based on the principle of establishing a positive classroom environment encompassing effective teacherstudent relationships [9]. When effective teacherstudent relationships exist, it becomes easier for the teacher to guide the students. Proper guidance of the child in school leads to moral and academic excellence [10]. This study therefore opines that when the teacher manages his or her class well, it creates room for positive behaviour of students, hence, academic excellence and character formation.

\section{Theoretical Framework of the Study}

The study hinges on the Classroom Management Theory. Thomas Gordon was the proponent of Classroom Management Theory. In his books: Teacher Effectiveness Training [11] and Discipline that Works: Promoting Self-Discipline in Children [12], Gordon explicitly highlighted how an effective classroom management enhances productivity in the students. The basic tenet of Gordon's approach to classroom management is the importance of developing meaningful and mutually beneficial relationships.

He believed that classroom discipline is best accomplished by helping students acquire an inner sense of self-control. He rejected traditional models of reward and punishment because they are based upon assertion of power and foster no intrinsic motivation. He beautifully brought it out this way; "using rewards to try to control children's behaviour is so common that its effectiveness is rarely questioned...the fact that rewards are used so often and unsuccessfully by so many teachers and parents proves they don't work very well..." [12]. Drawing from this quote, there is needed to focus on how students' conflicts can be resolved in a way that will improve their relationships with their teacher and peers.

In his Teacher Effectiveness Training, Gordon [11] expressed that there are four basic components to classroom management and these are; the behaviour window, active listening, I-message and no-lose conflict resolution. The purpose of the behaviour window is to ascertain who owns a problem and what skills to be used to solve it in case a problem exists. If the student for instance owns the problem, the second step for the teacher is to engage him or her in active listening. This occurs when a teacher listens and reflects back to a student their understanding of the conflict. 
This process communicates to the student that the teacher cares and is genuinely engaged in the conversation. If the teacher for example owns the problem, Gordon suggests that the second step of the resolution process begins with an I-message. This means that the teacher will initiate the conversation by explaining his or her feelings to the student. The purpose of the I-message is to confront someone else's misbehaviour without being confrontational. The final step is the no-lose conflict resolution. The purpose of this final step is to come up with a solution that everyone can be invested in [11].

Character formation is all about intrinsic good behaviour. Drawing from Gordon's theory therefore, it is worthy to mention that the only truly effective discipline is self-control developed internally in each student. To develop students' self-control, the teacher needs to give up his or her powers of control and authority and replace them with positive influence and role modelling. Learners of the $21^{\text {st }}$ century always want to be listened to especially in any difficult situation they found themselves. This is why at the beginning of the class for a new term for example, the teacher needs to sit and discuss with his or her students the expectations and what they hope to achieve by the end of the term. This would enable the learners establish their focus and model their behaviours and academic prowess.

Collective behavioural agreement is the key to maximum classroom management [13, 14]. Here, the teacher is expected to reach an agreement with the students on how they want the class to be until the end of the term. Each student is allowed to express his or her feelings. After the agreement, the points are to be displayed at the corner of the classroom and allowed to remain there where everybody can see them and lead by example. Another dimension is the proposition by Sosnowski [15]. According to him, in order to manage discipline effectively, there is need for teachers and the school administration to involve the learners in drawing up the rules and regulations of the school.

A critique to Thomas Gordon's Theory of Classroom Management shows that the basis for manageable classroom is developing positive relationships with students. Many other educators support this idea through the use of I messages and active listening $[13,14]$. The active listening strategy for example is employed when a student is given the opportunity to express him or herself with regard to an issue concerning him or her. For example, as Sosnowski [15] expressed, if a student routinely does not complete assignments, instead of creating consequence for the disruption, the teacher would speak with the student privately and listen to the student's reasons for his or her behaviour.
Thomas Gordon's Theory of Classroom Management has many positive aspects especially in his tenets of the behaviour window, active listening, Imessage and no-lose conflict resolution. Despite that, some of his critics especially, Kounin [16] disagreed with his approach. Kounin was a firm believer in preventing misbehaviours from occurring in the classroom by setting expectations at the start of the term or school year. He argued that Gordon focused mainly on resolving conflict after it arises. He further stated that Gordon did not take any preventive measures in avoiding conflict.

On the account of preventive measures in avoiding conflict, there is need to set expectations at the start of the school year, which shapes the behaviours of students. This is because students are likely to misbehave simply due to not being aware of how their teachers expect them to behave. After teachers elicit clear and concise expectations for their students, other forms in which to prevent misbehaviour include the creation of engaging lessons, teacher preparation and organisation plus a focus on movement [14]. This scenario is difficult to be found in most public high schools in Africa. Teachers are the sole authorities. The learners are seldom given the opportunity to discuss behavioural agreements in school. The administration reads out the rules and regulations and expects them to abide by them.

The researchers in the current study strongly believe that classroom management is the panacea to the incidences of indiscipline such as disobedience, disrespect, lying, bullying, examination malpractice, and truancy. Classroom management also helps students acquire the virtues of honesty, hard work, collaboration and responsibility. The researchers hold Gordon's Theory of Classroom Management to a greater esteem. That notwithstanding, they are of the opinion that sizable classroom of 1:30 with adequate teaching and learning facilities is an added advantage to classroom management. That is, it is easier to transfer values in students if the teacher has a manageable classroom of thirty students per class.

\section{Review of Related Literature on Classroom Management and Character Formation}

The management of human beings can be problematic if the manager lacks the techniques involved. It can also be rewarding if the manager follows and maintains relevant procedures in the act. Learners of high school age in Africa would like to act out in one way or the other due to their adolescent stage. These learners are always adventurous and are eager to explore different ways of learning. Sometimes, their creative ways become disruptive in the class and have adverse effect on their social life. Therefore, effective classroom management is the key to checkmate the excesses of these young learners and redirect them to positive pursuits. 
This review focuses on lesson preparation: instructional objectives and their achievement, and instructional strategies or skills. It also considers the teacher and learner performance activities, and the instructional resources employed in the process of teaching and learning. Instructional procedures that this review dwells on are observation, demonstration, collaborative learning, feedback or reinforcement, and role modelling. In addition, the review focusses on the use of group or varied learning experiences and skills in content development, learners' active participation in class, the teacher's language and his or her ability to engage learners in class. The teacher-learners' relationship, teacher's questioning skills and questioning type are also considered as bedrock in classroom management that translate to learners' character formation. Furthermore, the review looks at creativity in the use of instructional resources, the teacher's confidence, and the ability to create an environment conducive to teaching and learning as influences on the character formation of high school learners in Africa.

Mumtaz and Ahmad [17] did a quantitative study on classroom management strategies in Pakistan. The sample of the study consisted of 50 teachers of each public and private sectors, and the researchers used stratified random sampling technique to select the participants of the study. They developed a questionnaire three-point rating scale of 'yes,' 'no,' and 'undecided,' for data collection. The study disclosed that physical setting of the classroom, teacher-learner relationship, classroom rules, and varied learning activities and questioning techniques, immediate feedback and rewards, and effective instructional resources have positive influence on the learners' academic achievement and character formation. The study concludes therefore that classroom management strategies are a crucial part of teachers' success in creating a safe and effective learning environment for students. Specifically, that adequate preparation of the lesson is the key to learners' academic excellence and character formation.

In the same vein, Oliver, Wehby and Daniel [18] studied teacher classroom management and its effects on students' behaviour in the USA. They adopted a quantitative paradigm, specifically, the experimental design. The researchers randomly assigned to treatment and control or comparison conditions the participants of the study. The participants in the treatment and control conditions were matched and the matching variables included a pretest for at least one qualifying outcome variable or the study statistically controlled for pretest differences using ANCOVA. Their study reveals that teacher's classroom management practices have a significant, positive effect on decreasing problem behaviour in the classroom. Teachers who use effective classroom management can expect to experience improvements in student behaviour and improvements that establish the context for effective instructional practices to occur.

The missing link in their study is the inability to identify explicitly some of the classroom management techniques that could help improve students' behaviour, unlike Mumtaz and Ahmad [17]. However, their study disclosed that teacher proficiency with classroom management is necessary to structure successful environments that encourage appropriate student behaviour. Going further, Oliver, Wehby and Daniel [18] concurred with Oliver and Reschly [19] and Mumtaz and Ahmad [17], that adequate teacher preparation, therefore, is an important first step in providing content knowledge and opportunities to develop proficiency in classroom management. This is also the position of the current study. For the current study, when a teacher takes his or her time to prepare the lesson well, mapping out the specific instructional objectives that the students would achieve by the end of the lesson, supporting the objectives with concrete teaching skills and instructional materials, then, there is possibility of a high percentage of positive learning outcomes.

In his master's thesis that he submitted to the State University of New York, Gattellaro [20] affirms that classroom management has been an issue in all classrooms even to experienced teachers due to rapid cultural changes. In this qualitative study, he explains that teachers have varieties of techniques of maintaining discipline in class. One of the ways that the study identified was the use of green/yellow/red cards. The study emphasises that almost every student would like to go home with green card shown them due to fear of their parents' phone call when they received yellow or red cards in class.

To consolidate this, is the need for an intervention plan in the form of 'STARS' as a positive behaviour support model. This model aims at supporting a healthy and positive classroom environment. According to the study, STAR stands for Safety first, Take responsibility, Act as a team, Respect, and Show kindness. This slogan is inculcated in every learner and he or she does his or her best to follow it. This intervention plan can effectively work in the western society than in the African society, the study site. That notwithstanding, the essence of the behaviour support model is effective learner-teacher relationship. It is observed that yelling and punishment are no more vital in classroom management for the character formation of students. Rather, social rewards, verbal cues, and intrinsic motivation. In the context of the current study, we can look at them from the angles of feedback and reinforcement. This is in similarity with the theory of classroom management that the current study is anchored on. 
Furthermore, Gablinske [21] did a case study on the effect of student-teacher relationships on students' learning. Her qualitative study focused on the affective domain of learning. Classroom climate and teacher interaction behaviours were the major themes the study revealed that could translate to the cognitive and affective formation of the learner. The study emphasised that the teacher in collaboration with the students need to build a sense of community in the classroom and sense of ownership of classroom. This would help to manage disruptive behaviours in the class. In addition, there was need to give constant feedback to students in order to enhance their commitment to the rules of the classroom. This sounds theoretical! Can it really work in most public high schools in Africa?

It seems constant feedback, and specifically reinforcement can work effectively in enhancing the character formation of learners in Africa. Kinyanjui et al. [22] investigated classroom instruction reinforcement strategies in primary schools in Kikuyu district of Kenya. The study adopted mixed methods paradigm and was guided by Operant Conditioning Theory. The study disclosed that social reinforcement such as praise was the most popular reinforcement strategy used in the teaching and learning process. It stresses that learner's value verbal praise, and positive remarks in their written work. This finding also agrees with the scholars who emphasised positive classroom climate as the core to the transfer of knowledge and inculcation of values to the learners.

In buttressing classroom climate, Katharina [23] explains classroom climate as the social climate, the emotional and physical aspect of the classroom. Her study affirms that classroom climate influences students' growth and behaviour. That, a positive classroom climate supports student-teacher relationships, and it feels safe, respectful, welcoming and supportive of student learning. On the other hand, the study found that some teachers present lessons without much enthusiasm. In so doing, fail to show the students the value of the subject. The study therefore recommends that to transform the lives of the learners, the teacher needs to make the subject interesting and important, and motivate the learners by giving them constant feedback and reinforcement. The researchers of the current study believe that enthusiasm on the part of the teacher would make the learners to be interest in what goes on in the classroom. Therefore, constant reinforcement in terms of praise for good behaviours are likely to motivate learners to be disciplined in class. This praise needs to be sincere and natural and should be accompanied with appropriate gestures and actions.

The study of Goss, Sonnemann and Griffiths [24] confirms that it is vital that teachers create the right classroom climate for learning. This enhances character formation. According to their study, when students are engaged in class, they learn more. The study stresses that raising students' expectations, the teacher developing a rapport with students, establishing routines, and challenging students to participate and take risks affect how much students engage and learn in class. This concurs with the current study that effective classroom management is key to students' learning achievements.

\section{Conceptual Framework of the Study}

Figure 1 presents the conceptual framework of the study. The related literature on the phenomenon studied, and the theory that the study hinges on, informed the conceptual framework of the study.

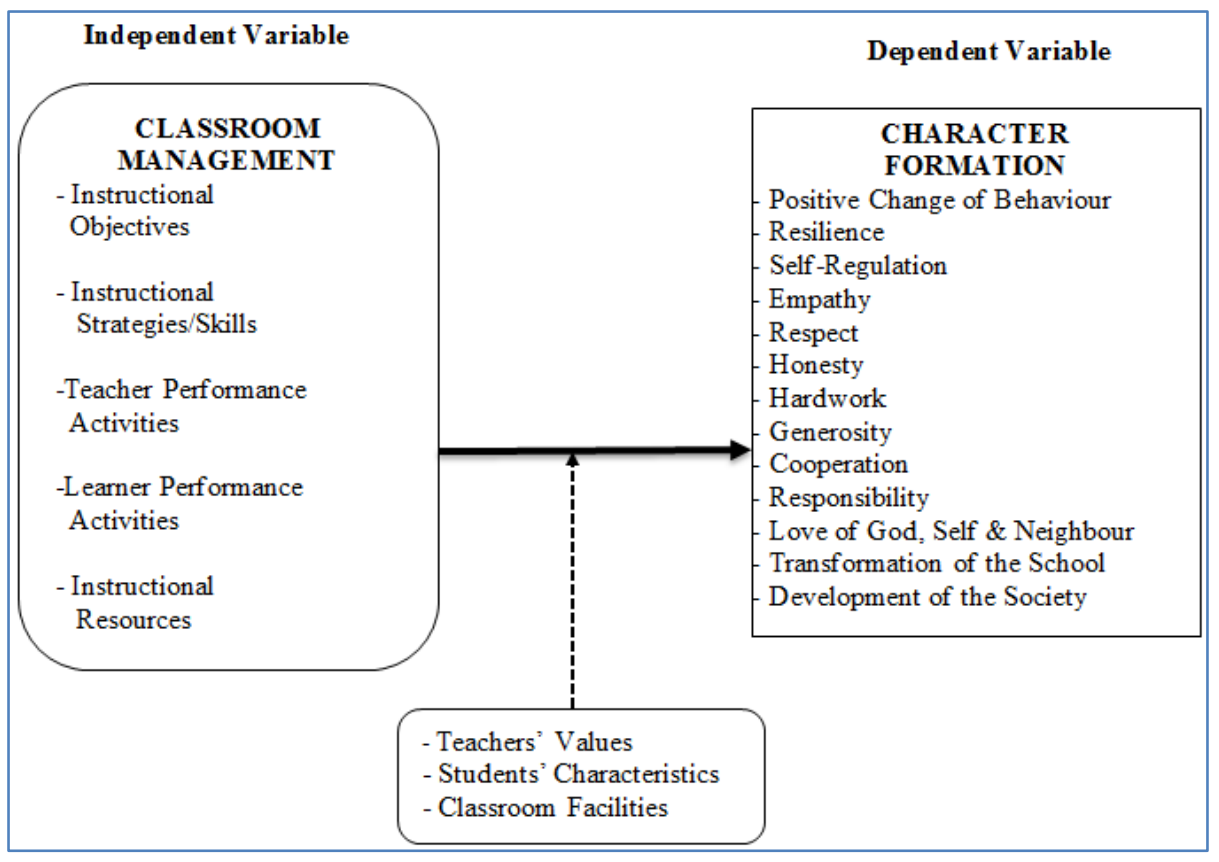

Fig-1: Character Formation 
Figure 1 shows the conceptual framework of the implications of classroom management on high school students' character formation in Africa. It is a relationship between the independent, intervening, and dependent variables. In this conceptual framework, classroom management is the independent variable. The independent variable comprises instructional objectives, instructional strategies/skills, teacher and learner performance activities, and instructional resources. The researchers ascertained the influence of these properties on the dependent variable.

Character formation is the dependent variable. In the conceptual framework, the dependent variable comprises disciplined and transformation-oriented students. This means that if the teacher concretely specifies what he or she wants the learners to achieve by the end of the lesson, adopts the right methodology and uses effective instructional materials in the classroom, classroom management becomes easier and yields to the character formation of the students.

In the conceptual framework of the study, there are also extraneous variables. These stand between the independent and dependent variables. They also have influence on the phenomenon being studied. These variables are teachers' values, students' characteristics, and classroom facilities.

\section{Classroom Observation: A Case Study}

In trying to ascertain how an effective classroom management could lead to the character formation of learners in high school in Africa, the researchers observed teaching and learning in a class. The observation was done in a public high school. It was a forty-minute lesson of Christian Religious Education (CRE). The number of students in the class; that is, the class size was thirty-three (33). The class was overcrowded due to lack of class space and basic teaching and learning facilities such as tables and chairs.

In Nigeria for example, it is worth to note that the national policy on education stipulates 1:40 as the teacher-student ratio [25]. Nevertheless, class size and teacher-student ratio are not the same. Class size is the number of learners in a teacher's room daily for whom the teacher is accountable; while the student-teacher ratio is generated by dividing the number of students in one school by all educators who serve in the school [26]. Hence, the study focused on the class size and not the teacher-student ratio. Therefore, the class size the study observed was 33 .

In some schools, these could mean a manageable classroom where there are instructional facilities. However, in this Case, it was not a manageable classroom, and it promoted indiscipline in class. The desks and tables in the class were so close to each other that there was no space left for the teacher to move round the class for individualised learning. Even so, some students who came late to class did not get chairs to sit on. They were forced to stand and some managed to share with their colleagues during the lesson. It was however, uncomfortable for them. This confirms the study of Maphosa and Mammen [27] that unmanageable classrooms lead to learner indiscipline in South African schools.

Availability of infrastructures and facilities in the right quantity and quality is necessary in attaining educational goals. Therefore, according to Ige [28], a school with inadequate classrooms and facilities such as chairs, lockers, libraries, textbooks, laboratories, and workshop will be uncomfortable for students to learn. The researchers in the current study strongly believe that when there are adequate facilities in the class that can accommodate the learners, teaching and learning become more learner-centred, and collaborative learning and teacher-learner interaction strengthened resulting to character formation and academic excellence.

Due to the overcrowded nature of the class, collaborative learning was not enhanced. Some students were making a noise in the class, while some concentrated on the disciplinary action being meted on one of them who disrespected the teacher on duty. The CRE teacher felt helpless, but continued teaching. This would have been a better opportunity for her to use that incident of disrespect and stress discipline in school. This is because according to Jay [29], the teacher has it as a duty to present different anecdotes to students, which would inspire and teach them to be morally responsible with their own actions; hence, character formation.

The students dressed decently in their school uniform. The teacher also dressed decently according to the stipulated dressing code of teachers in that region. The teacher was in white shirt and black skirt. The clothes were neatly fitting on her. It is presumably that the students might have been taught to dress decently as their teachers do. This supports Falade [30] that students learn by imitating other people's behaviour.

Their teacher has become their role model in terms of dressing. Nevertheless, there were few of them that did not put on their pairs of socks. Therefore, to establish discipline in students, the Classroom Management Theory of Gordon [11] recommends involving learners in drawing up behavioural agreements in school. Due to non-involvement of students in drawing up the behavioural agreements, they find it difficult to accept responsibility for their acts of indiscipline in school. This supports Bluestein [14] that effective classroom management is the key to the character formation of students. 
The teacher was time conscious to begin her lesson, but, in the process of teaching, she lost her time management and encroached into another teacher's lesson. This is where effective lesson plan is necessary whereby it becomes a guide to what the teacher teaches and the procedure he or she uses at any given period in the lesson development. This confirms Obaga [31] that, in the process of teaching CRE, time management is a factor that can either enhance or inhibit the transfer of knowledge and values in students for their character formation.

The lesson for the day was about the "Birth of Moses" (Exodus, 2:1-10 The African Bible). As the teacher began the lesson, she did not see the need to state the instructional objectives. This is in harmony with Kimosop [32] that majority of the teachers in Kenya were knowledgeable on objective writing and its usefulness, however, most of them did not set any objective while teaching. He differed from this and recommended that it is better for the teacher to let the learners know what is expected of them. According to him, this will encourage better instruction, more efficient learning results and better evaluation.

In the lesson development, the teacher setinduced the learners by a review of the previous lesson where they were looking at: "Leadership Qualities." She used the Socratic Method of teaching; questions and answers, in establishing knowledge transfer in the learners. This was quite commendable. Nevertheless, she did not ascertain the entry behaviour of students before starting the new topic: "The Birth of Moses." Entry behaviour describes the behaviour in the forms of acquired knowledge, values, attitudes and skills, which the learners have acquired or are able to demonstrate before entering into the present lesson. In Christian Religious Education, it enables the learner to associate his or her experience with that of the Biblical experience [5].

In her instructional technique, she used only the Socratic Method. This was not fair enough on the students since the Christian Religious Education curriculum [33] stipulated varied instructional techniques for the topic such as: reading of Biblical passages, group discussion, role-play and watching a film on Moses. These varied techniques would have helped in the transfer of values to the learners. Brady [34] agrees with the researchers and explains that the use of varied instructional techniques in teaching helps for value clarification in the learner.

Furthermore, the study observed that during the lesson, the learners did not have the opportunity to the read the Bible passage of the topic; Exodus, 2:1-10. At the start of her lesson, she asked: "Who has a Bible here?" It was discovered that no student had the Bible. She never commented on that, instead, she continued with her lesson. Apart from the Bible, it was also observed that none of the students had the CRE textbook. This concurs with Ngussa [35] who studied integration of media resources in Christian Religious Education in Kenya. The study found that the CRE teacher had textbook and the Bible, but the students had none. The study therefore concluded that it is very important for students to have their educational resources because if they do not have them, it could hinder their private study at home since most of them were day scholars.

On the teaching methodology, the teacher used expository method in her lesson throughout. She was 'talking' most of the time and seldom drew from the students' points and consolidated them. Despite having mastery of the subject matter, the lesson was teachercentred and not learner-centred. She also entertained 'chorus answers' in her class, which was not a good instructional approach in teaching and learning. This confirms that the learner-centred approaches of teaching are far-fetched in some public high schools in Africa. It also agrees with Ohwovorione [36], Falade [30], and Njoku and Njoku [37] that most secondary schools in Nigeria use the teacher-centred method in teaching Christian Religious Studies. The implication of this methodology is that, this approach inhibits easy transfer of values, virtues and morality to students.

Finally, her reinforcement and punishment techniques were fair. She drew from the responses of the students and consolidated their points. She rebuked noisemakers and called their attention to the lesson. It was a good classroom management technique. Nevertheless, due to time constraint, she was not able to evaluate her lesson in order to determine the extent to which the objectives were achieved. This was due to lack of proper time management. This created a big gap in the lesson. This is because if a teacher wants values and knowledge transferred to the learners, there is need to involve them in a practical manner. Giving the learners a practical exercise to do at home; such as visiting new born babies in the hospital, would have aided in the transfer of values and virtues to the learners; hence, character formation.

\section{CONCLUSIONS AND RECOMMENDATIONS}

This study has been able to establish that classroom management is a critical part of effective instruction. That precise and directional specific instructional objectives, instructional strategies, concise and concrete teacher and learner performance activities, and effective instructional resources breed disciplined and transformation-oriented students. Effective classroom management, which starts with adequate lesson preparation yields positive result in the process of teaching and learning. When students are motivated and allowed to link the lesson with their experience, they own the lesson and remain disciplined in class. Positive classroom climate enables the student to feel 
cared for and be engaged in school activities that lead to positive pursuits in life.

Similarly, in a poorly managed classroom, effective teaching and learning finds it difficult to thrive. This is because, if there are no apparent rules and regulations guiding students' behaviour in the classroom, they tend to be disorderly and disrespectful leading to incidences of indiscipline. Therefore, maintaining order in a classroom is basic in the act of teaching and learning. This is because a conducive classroom environment promotes students' character formation in high schools in Africa.

Drawing from the findings of the study therefore, the researchers make the following recommendations:

1. Since effective classroom management for the character formation of students starts with the adequate preparation of the lesson, teachers in high schools in Africa are encouraged to take this aspect of teaching and learning process serious. They should specifically consider the affective domain of learning in stating their instructional objectives. Similarly, they should be enthusiastic enough to provide students with highly explicit directions and explanations concerning the content of the lesson. In addition, teachers should encourage the initiative of learners. They should promote growth mind-set by allowing students to work ahead in certain topics, and do presentations in order to reinforce the teacher's lesson materials.

2. Reinforcement in form of verbal praise was also discovered to be a powerful tool in classroom management for the transfer of values in the learners. Therefore, teachers are advised always to use different reinforcement strategies in encouraging learners to achieve their learning outcomes. A teacher should recognise hard work by openly congratulating students, encouraging ideal behaviour and inspiring the class. Furthermore, a teacher should be passionate enough in his or her class in order to motivate the learners to learn.

3. Teacher's professional competence and confidence was also confirmed as the key to classroom management and character formation of students. Based on this therefore, teachers should establish a positive learning environment by showing their passion for the subject matter, and being active in moving among the students. This would help learners to identify with their teacher who they take as their role model.

4. Teachers are the key agents of curriculum implementation. The study found that the use of varied learning activities and instructional resources make learners remain focused in class, and it enhances the transfer of values in them. Therefore, teachers should use learnercentred approaches such as drama, role-play, debate, discussion, and demonstration, in teaching. Furthermore, they have to use varied instructional resources such as video clips, charts, maps, PowerPoint, and realia in teaching. These will help to sustain the interest of the students, help them to understand what they have been taught, and help transform their lives positively.

5. The study also observed that non-involvement of the learners in drawing up the rules and regulations of the class can hinder their ownership of the activities of the class. On this ground, the teacher is encouraged to ask students what they think is the acceptable and non-acceptable behaviours in the class. The teacher should encourage the students to suggest rules for the academic year. He or she should make sure that the behavioural agreements are written down and everybody gets a copy for reference. In any case of misbehaviour therefore, the teacher should avoid punishing the entire class, rather address isolated behaviour issues so as to avoid hurting the built relationship with the serious-minded students.

6. Since good behaviour thrives in a serene environment, the school administration should provide the right environment for the teaching and learning. First, principals need to reduce the class size; 1:30 is preferable for optimal delivery. This is because large class sizes interfere in the inculcation of values in each learner. Individualized learning thrives most in a manageable classroom where all teaching and learning facilities are available. Second, the principals should ensure that the Ministry of Education provides relevant and adequate instructional resources for the teaching and learning process.

\section{REFERENCES}

1. Osuji, G. E., \& Suleh, E. O. (2015). Role of institutions of higher learning in enhancing sustainable development in Kenya. Journal of Education and Practice, 6(16), 91-102.

2. Majawa, C. (2014). Patristic education. Nairobi: Scroll Technologies.

3. Ilechukwu, L. C., \& Ugwuozor, F. O. (2014). Evaluating religious education in Nigerian Catholic Schools. Journal of Education and Practice, 5(33), 25-32.

4. Dalhatu, I. I., \& Yunusa, A. A. (2013). Insight into delinquent and deviant behaviour among Students in secondary schools. Scientific Journal of Pure and Applied Sciences, 2 (5), 231-234.

5. Osuji, G. E. (2017). Influence of Christian Religious Studies implementation on students' character formation in public senior secondary 
schools in Owerri Municipal, Imo State, Nigeria (Unpublished doctoral dissertation). Nairobi: The Catholic University of Eastern Africa.

6. Brophy, J. (2006). History of research on classroom management. Handbook of classroom management: Research, practice, and contemporary issues, 17-43.

7. Elias, M. J., \& Schwab, Y. (2006). From compliance to responsibility: Social and emotional learning and classroom management. Handbook of classroom management: Research, practice, and contemporary issues, 309-341.

8. Jones, V. F. \& Jones, L. S. (2012). Comprehensive classroom management, creating communities of support and solving problems (10th ed.). Upper Saddle River, NJ: Pearson.

9. Wubbels, T., Brekelmans, M., Van Tartwijk, J., \& Admiraal, W. (1999). Interpersonal relationships between teachers and students in the classroom. In H.C. Waxman \& H.J. Walberg (Eds.), New directions for teaching practice and research. Berkeley, CA: McCutchan, 151-170

10. Osuji, G. E., \& Suleh, E. O. (2017). Curriculum and sustainable learning: Vade mecum for teacher education. Nairobi: CUEA Press.

11. Gordon, T. (1974). Teacher Effectiveness Training. New York: Crown.

12. Gordon, T. (1989). Discipline that works: Promoting self-discipline in children. California: Plume.

13. Christy, F. S. (2012). An in depth look into psychologist Thomas Gordon's classroom Management theory. Retrieved from https://mrsschlangensscience.wikispaces.com/Tho mas+Gordon+Classroom+Managem ent +Theory

14. Bluestein, J. (2014). Classroom management theorists and theories/Thomas Gordon. Retrieved from

https://en.wikibooks.org/wiki/Classroom_Manage ment_Theorists_and_Theories/Thomas_Gordon

15. Sosnowski, J. (2016). How to apply Thomas Gordon model of classroom management to the classroom. Retrieved from https://everdaylife.globalpost.com/apply-thomasgordon- model-classroom-management-classroom28763.html

16. Kounin, J. S. (1977). Discipline and group management in classrooms. Huntington, NY: RE Krieger.

17. Ahmad, M. (2010). Application of classroom management strategies in public and private sector at school level in Pakistan. International Journal of Library and Information Science, 2(9), 177-183.

18. Oliver, R. M., Wehby, J. H., \& Reschly, D. J. (2011). Teacher classroom management practices: Effects on disruptive or aggressive student behavior. Campbell Systematic Reviews, 7(1), 1-55.

19. Oliver, R. M., \& Reschly, D. J. (2007). Improving outcomes in general and special education: Teacher preparation and professional development in effective classroom management. NCCTQ Connections Paper: Washington, DC: National Comprehensive Center for Teacher Quality.

20. Gattellaro, J. P. (2014). Classroom management. Education and Human Development. Retrieved from

http://www.digitalcommons.brockport.edu/ehd_the ses $/ 400$

21. Gablinske, P. B. (2014). A case study of student and teacher relationships and the effect on student learning. Retrieved from http://digitalcommons.uri.edu/oa_diss

22. Kinyanjui, M. W., Aloka, P. J., Mutisya, S. K., Ndeke, F. N. \& Nyang'ara, N. M. (2015). Classroom instruction reinforcement strategies and factors that influence their implementation in Kenyan primary schools. Journal of Educational and Social Research, 5(3), 267-277.

23. Katharina, S. N. (2016). Effective classroom management \& positive teaching. English Language Teaching, 9(1), 163-172.

24. Goss, P., Sonnemann, J., \& Griffiths, K. (2017). Engaging students: Creating classrooms that improve learning. Retrieved from http://www.grattan.edu.au/.

25. Federal Ministry of Education. (2016). Administration and management of the education system. Retrieved from http://www.fmegovng.org/

26. Ikediashi, N. N., \& Amaechi, O. N. C. (2012). Pupil-teacher ratio: Implication for quality education in Nigeria primary schools. An International Journal of Arts and Humanities, 1(1), 257-264.

27. Maphosa, C., \& Mammen, K. J. (2011). How chaotic and unmanageable classrooms have become: Insights into prevalent forms of learner indiscipline in South African Schools. Anthropologist, 13(3) 185-193.

28. Ige, A. M. (2013). Provision of secondary education in Nigeria: Challenges and way forward. Journal of African Studies and Development, 5(1), $1-9$.

29. Jay, L. L. (2010). Applications: Theory of moral development. Retrieved from http://jaylordlosabia.blogspot.co.ke/2010/07/applic ations-theory-of-moral.html

30. Falade, D. A. (2015). Christian religious knowledge and the teaching of moral values in the Nigeria junior secondary schools: Problems and prospects. American International Journal of Research in Humanities, Arts and Social Sciences, 15(143), 148-151.

31. Obaga, A. M. (2009). The role of Christian Religious Education in character formation among the primary school youth, Nyansiongo Central Division in Borabu District, Kenya (Doctoral dissertation). The Catholic University of Eastern Africa, Nairobi, Kenya.

32. Kimosop, E. (2015). Teacher preparedness for effective classroom instruction of the secondary 
school Christian Religious Education curriculum in Kenya. International Journal of Scientific Research and Innovative Technology, 2(12), 63-72.

33. Nigerian Educational Research and Development Council (NERDC) (2012). Senior secondary school curriculum: Christian Religious Studies for SS 1-3. Abuja: NERDC.

34. Brady, L. (2011). Teacher values and relationship: Factors in values education. Australian Journal of Teacher Education, 36(2), 56-66.

35. Ngussa, B. M. (2015). Integration of media resources in Christian Religious Education: A case study of secondary schools in Chemundu zone,
Kenya. International Journal of Academic Research in Business and Social Sciences, 5(1), 197-211.

36. Ohwovorione, P. A. (2013). Moral education in Nigerian secondary schools: A realistic approach. Standard Journal of Education and Essay, 1(2), 35-39.

37. Njoku, N. C., \& Njoku, D. I. (2015). Attaining Christian Religious Studies learning outcomes through effective teaching methods among secondary school pupils in South East geopolitical zone of Nigeria. International Journal of Education, Learning and Development, 3(8), 9-16. 